\title{
OLED: 引领显示技术革命
}

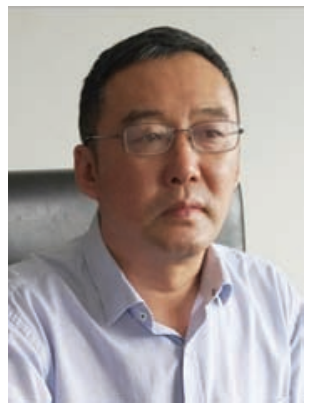

\section{马族光}

1963 年生, 教授, 博士生导 师. 2001 年获国家杰出青年 科学基金, 2006 年受聘教育 部“长江学者”特聘教授, 2013 年入选“国家百千万工 程”. 曾获国家自然科学二 等奖(2009 年, 第一完成人). 作为负责人主持国家自然科 学基金重大项目(有机聚合 物光电信息材料的基础研 究)、国家自然科学基金重点 项目(有机聚合物电致发光 材料的三线态激子问题及高 效率器件研究). “973”计划 子课题及其他国家级科研项 目 10 余项. 发表 SCI 收录论 文 300 余篇, 论文被 SCI 他 引 7000 余次.
1987 年, 柯达公司华人科学家邓青云报道了高效率有机电致发光器件 (OLED), 开启了 OLED 新时代. 历经 30 年发展, OLED 已从实验室走向千家万 户, 应用领域包括手机显示屏、大尺寸(>55 英寸)OLED 电视机、仪器仪表、照 明等，我国 OLED 产业发展迅速，已有多条生产线投产，未来 3 5 年 OLED 面 板产能将领先全球. 进一步提升 OLED 产品的质量、增加其市场竞争力, OLED 器件的效率、寿命需要大幅提高, 成本需要进一步降低. 业内已有共识, 制约 OLED 发展的关键因素之一是材料. 高性能 OLED 材料属商业机密, 国外对中 国实施封锁，因此自主研发具有我国知识产权的新材料具有重要的战略意义. 同时, 发光材料科学自身还有待完善, 相关研究科学意义同样重要. 材料设计 中的新概念与创新思路是源头创新的基础.

从发光材料的发展历程分析, 以 Alq3 为代表的荧光分子作为第一代 OLED 材料(专利权由柯达公司掌握), 因能量利用效率低( $<25 \%$, 受激子统计限制) 已 逐渐被新材料替代; 第二代 OLED 材料(当前主流材料)是以铱(Ir)配合物为代表 的磷光材料(专利权为美国 UDC 公司掌握), 该类材料的能量利用效率可接近 $100 \%$, 但是仍存在诸多问题. 当前学术与产业界正聚焦研发兼具高能量利用效 率与廉价的新一代(第三代)材料, 研究者希望不用稀有贵重金属元素、或者全 部用有机高能量利用效率材料, 实现资源丰富、高性价比材料, 利用新一代材 料突破当前 OLED 技术屏障. 当前新一轮 OLED 材料的全球竞争的序幕已开启, 国际发展趋势与我国 OLED 产业布局已形成交汇，为我国实施创新材料计划提 供了难得的机遇.

OLED 材料的研发是一个复杂的工程, 需要多学科的交叉, 例如合成化学、 光化学、固体物理、半导体器件物理等. 同时需要这些知识的交汇产生新的设 计理念、特殊物理效应(新原理), 这对新概念材料设计意义重大, 例如磷光材 料、热活化延迟荧光材料(TADF)、杂化激发态材料(HLCT)、自由基双线态材 料等.

鉴于新型 OLED 材料设计重大科学问题及重要产业应用前景, 《科学通报》 特组织出版此专题, 邀请了从事新概念材料的研究人员撰写研究进展, 展示我 国研究人员在 OLED 材料新机制、新结构、新概念等方面的成果. 希望借此专 题的出版对我国 OLED 材料研究人员有所帮助. 在此对参与此专题撰稿、审稿、 编辑人员的辛勤劳动表示衷心感谢.

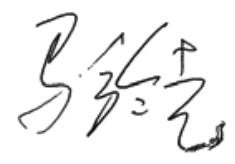

华南理工大学发光材料与器件国家重点实验室 